\title{
Review of the temperature and holding time effects on hydroxyapatite fabrication from the natural sources
}

\author{
Akhlis Rahman Sari Nurhidayat ${ }^{1 *}$, A.P. Bayuseno ${ }^{1,2}$, Rifky Ismail ${ }^{1,2}$, Rilo Berdin Taqriban ${ }^{1,2}$ \\ ${ }^{I}$ Department of Mechanical Engineering, Faculty of Engineering, Universitas Diponegoro, Indonesia \\ ${ }^{2}$ Center for Biomechanics Biomaterials Biomechatronics and Biosignal processing (CBIOM3S), Universitas Diponegoro, Indonesia \\ Email : akhlisrahman22@gmail.com
}

\begin{abstract}
Biomaterial development is currently being carried out to help people who have daily needs. Hydroxyapatite has biocompatibility properties and suitables for the use as a biomaterial. Hydroxyapatite can be found in natural sources sometimes as waste. One of the hydroxyapatite fabrication methods is calcination process. Calcination and sintering are used to obtain the desired $\mathrm{Ca} / \mathrm{P}$ ratio of the hydroxyapatite. This paper reviews several research which have been published by researchers to withdraw the connection during calcination process, with respect to the temperature and holding time effects on hydroxyapatite fabrication from the natural organism. The effect of temperature and holding time determines the yield of $\mathrm{Ca} / \mathrm{P}$ ratio which affects the resulting mechanical properties. Choosing the right temperature and holding time will produce $\mathrm{Ca} / \mathrm{P}$ which meets the standard.
\end{abstract}

Keywords: Calcination, $\mathrm{Ca} / \mathrm{P}$, Hydroxyapatite, Mechanical properties, Sintering.

Article History: Received 23 March 2021; Accepted 17 April 2021; Available online: 20 April 202

DOI: $10.14710 /$ jbiomes.2021.v1i1.27-31

\section{INTRODUCTION}

The use of biomaterials at this time helps the daily activities of people who have limitations caused by disease. Biomaterials are expected to be able to replace the same structure and function as damaged organs. Ceramic material is a material commonly used in biomaterials. Ceramics that are easy to process in various forms are very suitable for biomaterial needs, especially for implants. One of the biomaterials that continues to be improved in its process and use is hydroxyapatite (HAp). Hydroxyapatite can be used as a bone strengthener, tooth [1], drug delivery [2], or coating for implants.

Hydroxyapatite which will be used as an implant in the body must have biocompatibility that has no side effects in the body. It is should be nontoxic, noncarcinogenic, nonallergic, noninflammatory, biocompatible, and biofunctional for its lifetime in the host. HAp can be obtained by synthesizing or extracting. Natural HAP can be found in bio-waste consisting of animal antlers [3], mammal bones [4-6], fish bones [4, 7-10], clamshells [4, 11-14], and eggshells [4, 15-17].

Several methods have been developed in the synthesis of HAp including mechanochemical synthesis [18-19], precipitation methods [20-23], microwave processing [24], solid-state [25], and wet chemical methods [23, 26-27]. One method used in the extraction of HAp from natural sources is calcination $[8,10,12,16,17]$. Calcination temperature will affect the formation of HAp powder. Upon completion of the sintering process carried out in the formation of the HAp pellet. The influence of temperature will have an impact on the mechanical properties that will be obtained
[28-32]. For more specific uses, HAp will be compatible with other materials.

HAp has calcium and phosphate by replacing the recommended ones. Each material and process will produce a different $\mathrm{Ca} / \mathrm{P}$ ratio. Selection of temperature and holding time during calcination will affect the ratio. The ratio value of $\mathrm{Ca} / \mathrm{P}$ already has a set of standards. Effect of other elements on the Hap is likely to affect the $\mathrm{Ca} / \mathrm{P}$ value.

Its mechanical properties will also be affected by the sintering process. Sintering temperature will produce different results depending on the source of the material used. These parameters will be adjusted to which the HAp will be used, for example, implanted HAp into fractured human bone as bone graft. HAp properties correspond to the function and mechanical properties of the fractured bone that will be implanted.

In this paper, review effect of temperature used in the calcination and sintering processes will be determined. This paper discusses the HAp product sourced from natural materials which always available and often found in the environment, sometimes as waste.

\section{HYDROXYAPATITE SOURCES AND FABRICATION}

Hydroxyapatite can be extracted from bio-waste in the nearby environment. The use of bio-waste as the main source of natural hydroxyapatite is intended to support the movement to reduce waste and upscaling the economic value of the waste itself. Table 1 shows some bio-waste and the methods used. 
Table 1

Summary of materials and methods using Calcination to extract Hap

\begin{tabular}{|c|c|c|c|c|c|c|}
\hline Source & Method & ${ }^{\circ} \mathrm{C}$ & $\mathrm{H}$ & $\mathrm{Ca} / \mathrm{P}$ & Product & ref \\
\hline \multirow{8}{*}{$\begin{array}{l}\text { Bovine } \\
\text { bone }\end{array}$} & Calcination & 850 & - & - & HAp & [29] \\
\hline & Calcination & 600 & - & - & HAp & [33] \\
\hline & Calcination & 900 & - & - & HAp & [33] \\
\hline & Calcination & 1200 & - & - & HAp & [33] \\
\hline & Calcination & 700 & 3 & - & HAp & [34] \\
\hline & Calcination & 900 & 3 & - & HAp & [34] \\
\hline & Calcination & 1100 & 3 & - & HAp & [34] \\
\hline & Calcination & 750 & 4 & - & HAp & [24] \\
\hline \multirow{3}{*}{$\begin{array}{l}\text { Porcine } \\
\text { Bone }\end{array}$} & Calcination & 600 & - & - & HAp & [33] \\
\hline & Calcination & 900 & - & - & HAp & [33] \\
\hline & Calcination & 900 & - & - & HAp & [33] \\
\hline \multirow{5}{*}{$\begin{array}{l}\text { Caprine } \\
\text { Bone }\end{array}$} & Calcination & 900 & 2 & 2.2 & HAp & [35] \\
\hline & Calcination & 1000 & 2 & 1.9 & $\begin{array}{l}\text { HAp } \\
\text { TCP }\end{array}$ & [35] \\
\hline & Calcination & 1100 & 2 & 1.8 & $\begin{array}{l}\text { HAp } \\
\text { TCP }\end{array}$ & [35] \\
\hline & Calcination & 1200 & 2 & 1.8 & $\begin{array}{l}\text { HAp } \\
\text { TCP }\end{array}$ & [35] \\
\hline & Calcination & 1300 & 2 & 1.7 & $\begin{array}{l}\text { HAp } \\
\text { TCP }\end{array}$ & [35] \\
\hline \multirow{2}{*}{$\begin{array}{l}\text { Egg } \\
\text { Shell }\end{array}$} & Calcination & 700 & 2 & - & HAp & [16] \\
\hline & Calcination & 900 & 3 & - & HAp & [17] \\
\hline \multirow{2}{*}{$\begin{array}{l}\text { Clam } \\
\text { Shell }\end{array}$} & Calcination & 900 & 5 & 1.67 & HAp & [12] \\
\hline & Calcination & 1000 & 5 & 2.18 & $\begin{array}{l}\text { HAp } \\
\text { TTCP }\end{array}$ & [12] \\
\hline \multirow{13}{*}{$\begin{array}{l}\text { Fish } \\
\text { Bone }\end{array}$} & Calcination & 600 & - & 1.86 & HAp & [36] \\
\hline & Calcination & 950 & - & 1.84 & HAp & [36] \\
\hline & Calcination & 700 & 1 & - & HAp & [8] \\
\hline & Calcination & 700 & 2 & 1.83 & HAp & [10] \\
\hline & Calcination & 700 & 2 & 1.8 & HAp & {$[10]$} \\
\hline & Calcination & 700 & 2 & 1.82 & HAp & [10] \\
\hline & Calcination & 700 & 2 & 1.69 & HAp & [10] \\
\hline & Calcination & 600 & 2 & 1.53 & HAp & [37] \\
\hline & Calcination & 600 & - & 1.87 & HAp & [36] \\
\hline & Calcination & 950 & - & 1.89 & HAp & [36] \\
\hline & Calcination & 600 & 2 & 1.51 & HAp & [37] \\
\hline & Calcination & 600 & 2 & 1.55 & HAp & [37] \\
\hline & Calcination & 600 & 2 & 1.42 & HAp & [37] \\
\hline \multirow{5}{*}{$\begin{array}{l}\text { Fish } \\
\text { Scale }\end{array}$} & Calcination & 200 & 1 & - & HAp & [22] \\
\hline & Calcination & 400 & 1 & - & HAp & [22] \\
\hline & Calcination & 800 & 1 & - & HAp & [22] \\
\hline & Calcination & 1000 & 1 & - & HAp & [22] \\
\hline & Calcination & 1200 & 1 & 1.71 & $\begin{array}{l}\text { HAp } \\
\text { TCP }\end{array}$ & [22] \\
\hline
\end{tabular}

$\mathrm{H}=$ Time (Hour)
The trace elements in the hydroxyapatite powder will produce different ratios for each source. Mass spectrometry testing will show all the elements contained in the powder other than $\mathrm{Ca}$ and $\mathrm{P}$. The temperature and holding time given also affect the results of the ratio.

The elements contained in raw materials can affect the resulting $\mathrm{Ca} / \mathrm{P}$ value. Other elements which could be found in HAp are $\mathrm{Al}, \mathrm{Na}, \mathrm{Mg}$, and $\mathrm{Sr}$. Other elements such as $\mathrm{Na}$ and $\mathrm{Mg}$ can substitute $\mathrm{Ca}$ [38]. $\mathrm{Na}$ and $\mathrm{Mg}$ can help enhance the growth/development of bones and teeth.

The research conducted by Vidhya, et. al [39] showed that the $\mathrm{Mg}$ content in eggshells is $0.65 \%$ At. Meanwhile, the research conducted by Nam, et. al. [10] using catfish as HAp raw material informs that the $\mathrm{Mg}$ content in HAp by calcination process at $700{ }^{\circ} \mathrm{C}$ was $2.03 \mathrm{mg}$. In the research of Goto and Sasaki [37] and Nam, et. al. [10] using tuna fish resulted in different amounts of $\mathrm{Mg}$. This can be caused by the environment or the habitat the tuna lived in.

Using the substitution equation, the molar ratio of $(\mathrm{Ca}+$ $\mathrm{Mg}+0.5 \mathrm{Na}+0.5 \mathrm{~K}) / \mathrm{P}$ is not much different from the $\mathrm{Ca} / \mathrm{P}$ molar ratio. However, the increasing of molar ratio occurred in Goto and Sasaki [37] from 1.55 to 1.63 while in Nam, et. al. [10] from 1.69 to 1.71 which are both using tuna as raw material.

\section{ChaRACTERISTICS OF THE HYDROXYAPATITE FROM DISTINCT FABRICATION}

The characteristics of HA from the calcination process are known through the $\mathrm{Ca} / \mathrm{P}$ ratio that complies with the standard 1.67 molars. In the study of Goto and Sasaki [37] in Table 1 using fish as a material at a temperature of $600{ }^{\circ} \mathrm{C}$ $\mathrm{Ca} / \mathrm{P}$ values below the specified stoichiometry. While research conducted by Nam, et.al [10] using different fish bones with temperature calcination of $700{ }^{\circ} \mathrm{C}$ with a holding time of 2 hours produces a range of $1.69-1.83 \mathrm{Ca} / \mathrm{P}$. Such results indicate the potential for a fishbone temperature is at $600-700{ }^{\circ} \mathrm{C}$ with a holding time of 2 hours.

The study from Alif, et.al [12] which used clamshell as material needs 5 hours holding time to get a $\mathrm{Ca} / \mathrm{P}$ of 1.67 following the required standards. Calcination temperature and holding time that will determine the value of calcium and phosphate needed in the HAp need further synthesis to get results that are under the standards.

In Figure 1, some $\mathrm{Ca} / \mathrm{P}$ values of animal bones are calculated concerning the temperature used in the heat agreement. In the bovine study of Ramesh, et.al [40] compared to Niakan, et. al [5] the Ca / $\mathrm{P}$ value produced has a large enough value. At a temperature of $1000{ }^{\circ} \mathrm{C} \mathrm{Ca} / \mathrm{P}$ values produced by Ramesh, et.al more values are temporarily standardized in Niakan, et. al is much higher. The decrease in $\mathrm{Ca} / \mathrm{P}$ values in bovine [5] at temperatures of $800{ }^{\circ} \mathrm{C}$ to $1000{ }^{\circ} \mathrm{C}$ is stable, in contrast to bovine [40] which decreases dramatically at $1000{ }^{\circ} \mathrm{C}$. 


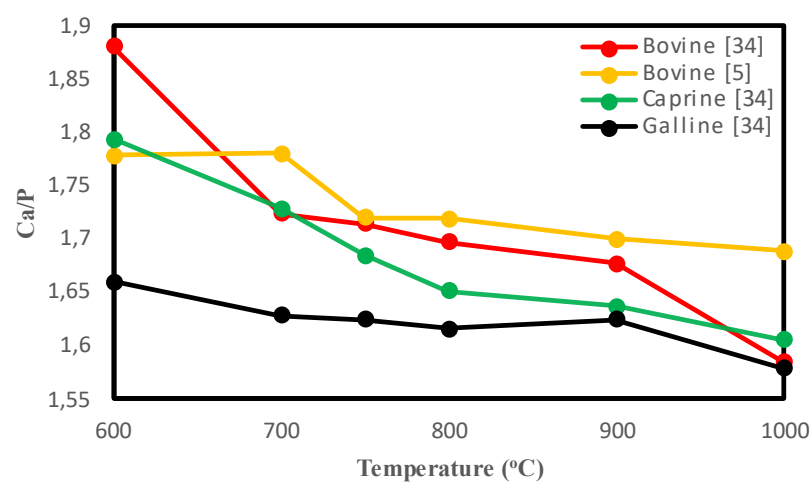

Fig 1. Effect of temperature on $\mathrm{Ca} / \mathrm{P}$ values

Increasing the temperature used in the calcination will cause the formation of $\beta$-HAp which affects the $\mathrm{Ca} / \mathrm{P}$ ratio value. The higher calcination temperature used, the higher possibility of TCP will form. It will affect the total HAp mass, because the more TCP forms, the least HAp will forms [41]. It was known that $\beta$-TCP appears at $1000{ }^{\circ} \mathrm{C}$ calcinaction temperature, which was reported in the study of Barua, et. al [35].

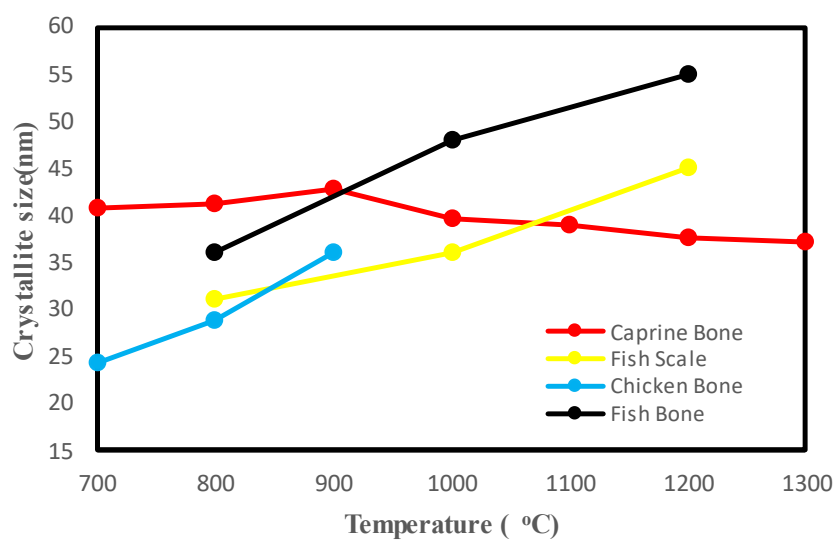

Fig 2. Comparison of crystallite sizes from several HA sources

The temperature calcination will also be the crystallite size shown in Figure 2 between caprine bone [35], fish scale [22], chicken bone [43], and fishbone [44]. An increase in temperature will increase the size of crystallite [22, 42]. The crystal size will also affect the mechanical properties of the product generated.

Figure 3. presents the ratio of relative density $(\%)$ to the increase in sintering temperature used. An increase in relative density occurs with an increase in temperature. In the study of Ramesh, et.al [16] relative density reaches a maximum value at a temperature of $1350{ }^{\circ} \mathrm{C}$. The use of eggshells $[15,16]$ and fishbone [8] in the relative values obtained can reach a maximum value at a temperature of $1250^{\circ} \mathrm{C}$.

While in calcinated caprine bone [35] the maximum value is around $90 \%$. In the research of Piccirillo, et. al [8] the sintering process is done after the calcination process which makes the value of the resulting relative density above $95 \%$. This will cause the porosity of HA to be smaller with increasing sintering temperature [46].

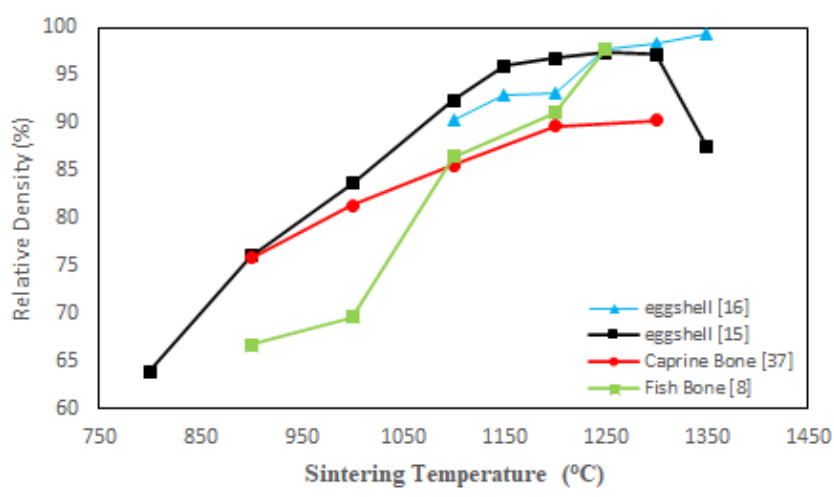

Fig 3. Comparison of relative density to heat treatment

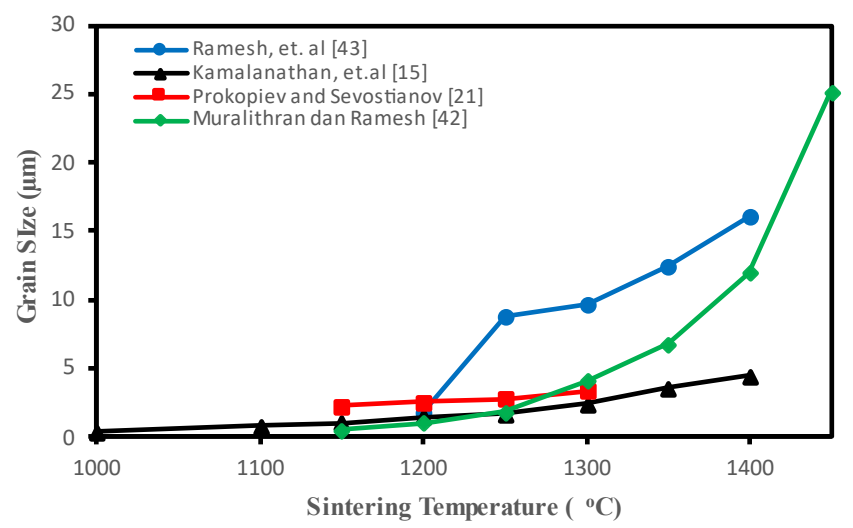

Fig 4. Comparison of grain size and sintering temperature

Similarly, the relationship between sintering temperature and relative density, from 4 studies [15, 21, 42, 43] the value is almost the same at $1200{ }^{\circ} \mathrm{C}$ at the grain size shown in Figure 4. The increase in sintering temperature in grain size is obtained. When connected between the value of relative density with the value of grain size has a different value at vulnerable sintering temperatures of $1200{ }^{\circ} \mathrm{C}$ and $1250{ }^{\circ} \mathrm{C}$. By heating above $1300{ }^{\circ} \mathrm{C}$, research by Muralithran and Ramesh [45] experienced a large grain size enlargement. In contrast to Prokopiev and Sevostianov [21], the increase in sintering temperature does not significantly increase grain size. HA unit cells did not experience the size change reported in Sunil, et al [9].

Figure 4. Comparison of grain size and increasing the sintering temperature will change the mechanical properties of the HAp itself. The effect of grain size enlargement will have an impact on the value of hardness and fracture toughness that HAp has. Figure 5 shows the effect of sintering temperature on HAp hardness. Some studies experience maximum hardness values at temperatures of $1250{ }^{\circ} \mathrm{C}[15,16,42]$ and $1300{ }^{\circ} \mathrm{C}$ [48].

In contrast to other studies, in the ark clamshell [49] the resulting value is not too large at an increase in temperature. The influence of grain size during the sintering process affects the fracture toughness value presented in Figure 6. Increasing sintering temperature will increase the fracture that occurs [50]. The optimal fracture toughness value is obtained at a sintering temperature of $1250{ }^{\circ} \mathrm{C}$. 


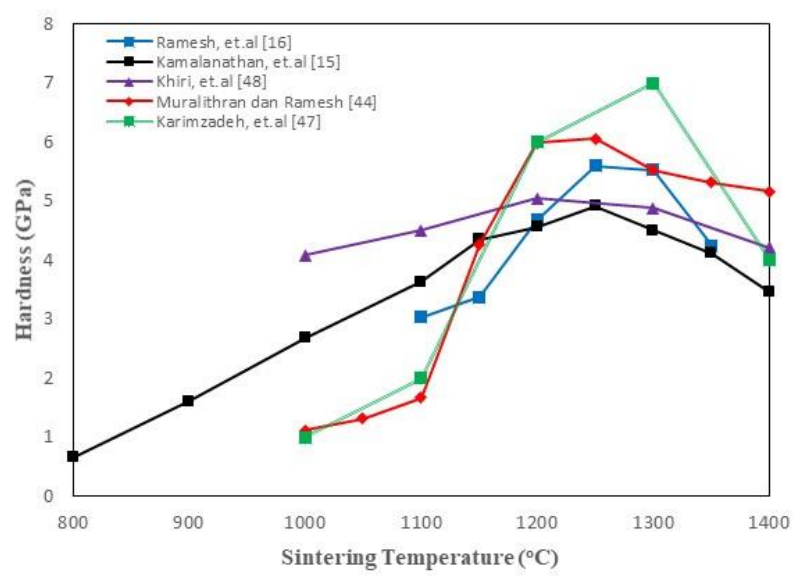

Fig 5. Effect of sintering temperature on the value of hardness

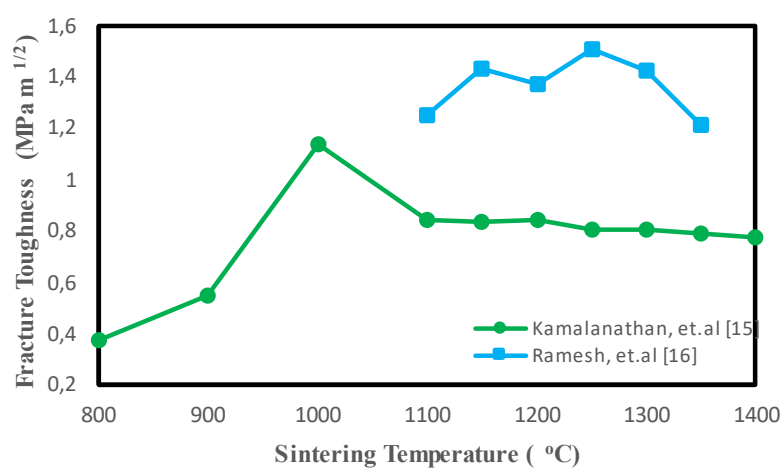

Fig 6. Effect of sintering temperature on fracture toughness values

The hardness of the Hap will be adjusted according to its use. Hardness of human cortical bone in a study by Mirzaali, et. al. [51] was confirmed at $455 \pm 78 \mathrm{MPa}$. Based on this results, it is necessary to know the predicted activities of the patients who will use the HAp product as bone graft. The load and direction of the bone movements also need to be predicted, whether compression, torsion, or tensions.

\section{Conclusion}

The calcination process for each base material has an uncertain time and temperature to obtain a standardized $\mathrm{Ca} / \mathrm{P}$. Increase in sintering temperature will affect the mechanical properties of HA. Selection of temperature calcination and sintering is optimized for the use of HA. an increase in sintering temperature will affect the mechanical properties of HA. The choice of temperature calcination and sintering is optimized for the use of HA.

\section{REFERENCES}

[1] S. Mazumder, A. K. Nayak, T. J. Ara, and M. S. Hasnain, Hydroxyapatite composites for dentistry. Elsevier Inc., 2018.

[2] I. Partheniadis, T. Papanikolaou, M. F. Noisternig, U. J. Griesser, N. Kantiranis, and I. Nikolakakis, "Structure reinforcement of porous hydroxyapatite pellets using sodium carbonate as sintering aid: Microstructure, secondary phases and mechanical properties," $A d v$. Powder Technol., vol. 30, no. 8, pp. 1642-1654, 2019.
[3] L. González-Rodríguez, M. López-Álvarez, S. Astray, E. L. Solla, J. Serra, and P. González, "Hydroxyapatite scaffolds derived from deer antler: Structure dependence on processing temperature," Mater. Charact., vol. 155, no. June, 2019.

[4] N. A. S. Mohd Pu'ad, P. Koshy, H. Z. Abdullah, M. I. Idris, and T. C. Lee, "Syntheses of hydroxyapatite from natural sources," Heliyon, vol. 5 , no. 5, p. e01588, 2019.

[5] A. Niakan et al., "Sintering behaviour of natural porous hydroxyapatite derived from bovine bone," Ceram. Int., vol. 41, no. 2, pp. 3024-3029, 2015.

[6] E. C. Victoria and C. Robinson M, "Comparative studies on synthesis and sintering studies of biologically derived hydroxyapatite from Capria hircus (Goat) and Bos primigenius (Bovine)," Vacuum, vol. 160, no. November 2018, pp. 378-383, 2019.

[7] P. Terzioğlu, H. Öğüt, and A. Kalemtaş, "Natural calcium phosphates from fish bones and their potential biomedical applications," Mater. Sci. Eng. C, vol. 91, no. September 2017, pp. 899-911, 2018.

[8] C. Piccirillo, R. C. Pullar, E. Costa, A. Santos-Silva, M. M. E. Pintado, and P. M. L. Castro, "Hydroxyapatite-based materials of marine origin: A bioactivity and sintering study," Mater. Sci. Eng. C, vol. 51, pp. 309-315, 2015.

[9] B. R. Sunil and M. Jagannatham, "Producing hydroxyapatite from fish bones by heat treatment," Mater. Lett., vol. 185, no. September, pp. 411-414, 2016.

[10] P. V. Nam, N. Van Hoa, and T. S. Trung, "Properties of hydroxyapatites prepared from different fish bones: A comparative study," Ceram. Int., vol. 45, no. 16, pp. 20141-20147, 2019.

[11] S. Bramhe, T. N. Kim, A. Balakrishnan, and M. C. Chu, "Conversion from biowaste Venerupis clam shells to hydroxyapatite nanowires," Mater. Lett., vol. 135, pp. 195-198, 2014.

[12] M. F. Alif, W. Aprillia, and S. Arief, "A hydrothermal synthesis of natural hydroxyapatite obtained from Corbicula moltkiana freshwater clams shell biowaste," Mater. Lett., vol. 230, pp. 40-43, 2018.

[13] S. C. Wu, H. C. Hsu, S. K. Hsu, C. P. Tseng, and W. F. Ho, "Preparation and characterization of hydroxyapatite synthesized from oyster shell powders," Adv. Powder Technol., vol. 28, no. 4, pp. 1154-1158, 2017.

[14] J. Chen, Z. Wen, S. Zhong, Z. Wang, J. Wu, and Q. Zhang, "Synthesis of hydroxyapatite nanorods from abalone shells via hydrothermal solid-state conversion," Mater. Des., vol. 87, pp. 445449, 2015.

[15] P. Kamalanathan et al., "Synthesis and sintering of hydroxyapatite derived from eggshells as a calcium precursor," Ceram. Int., vol. 40, no. PB, pp. 16349-16359, 2014.

[16] S. Ramesh et al., "Direct conversion of eggshell to hydroxyapatite ceramic by a sintering method," Ceram. Int., vol. 42, no. 6, pp. 78247829, 2016

[17] V. Trakoolwannachai, P. Kheolamai, and S. Ummartyotin, "Characterization of hydroxyapatite from eggshell waste and polycaprolactone (PCL) composite for scaffold material," Compos. Part B Eng., vol. 173, no. April, 2019.

[18] A. Fahami, R. Ebrahimi-Kahrizsangi, and B. Nasiri-Tabrizi, "Mechanochemical synthesis of hydroxyapatite/titanium nanocomposite," Solid State Sci., vol. 13, no. 1, pp. 135-141, 2011.

[19] S. H. Rhee, "Synthesis of hydroxyapatite via mechanochemical treatment," Biomaterials, vol. 23, no. 4, pp. 1147-1152, 2002.

[20] S. Padilla, M. Vallet-Regí, M. P. Ginebra, and F. J. Gil, "Processing and mechanical properties of hydroxyapatite pieces obtained by the gelcasting method," J. Eur. Ceram. Soc., vol. 25, no. 4, pp. 375-383, 2005.

[21] O. Prokopiev and I. Sevostianov, "Dependence of the mechanical properties of sintered hydroxyapatite on the sintering temperature," Mater. Sci. Eng. A, vol. 431, no. 1-2, pp. 218-227, 2006.

[22] S. Paul et al., "Effect of trace elements on the sintering effect of fish scale derived hydroxyapatite and its bioactivity," Ceram. Int., vol. 43, no. 17, pp. 15678-15684, 2017.

[23] A. Fihri, C. Len, R. S. Varma, and A. Solhy, "Hydroxyapatite: A review of syntheses, structure and applications in heterogeneous catalysis," Coord. Chem. Rev., vol. 347, pp. 48-76, 2017.

[24] M. N. Hassan, M. M. Mahmoud, G. Link, A. A. El-Fattah, and S. Kandil, "Sintering of naturally derived hydroxyapatite using high frequency microwave processing," J. Alloys Compd., vol. 682, pp. 
107-114, 2016.

[25] S. Pramanik, A. K. Agarwal, K. N. Rai, and A. Garg, "Development of high strength hydroxyapatite by solid-state-sintering process," Ceram. Int., vol. 33, no. 3, pp. 419-426, 2007.

[26] C. Zhou et al., "Mechanical and biological properties of the micro/nano-grain functionally graded hydroxyapatite bioceramics for bone tissue engineering," J. Mech. Behav. Biomed. Mater., vol. 48, pp. 1$11,2015$.

[27] A. Yelten-Yilmaz and S. Yilmaz, "Wet chemical precipitation synthesis of hydroxyapatite (HA) powders," Ceram. Int., vol. 44, no. 8, pp. 9703-9710, 2018.

[28] M. Yetmez, Z. E. Erkmen, C. Kalkandelen, A. Ficai, and F. N. Oktar, "Sintering effects of mullite-doping on mechanical properties of bovine hydroxyapatite," Mater. Sci. Eng. C, vol. 77, pp. 470-475, 2017.

[29] S. Salman et al., "Sintering effect on mechanical properties of composites of natural hydroxyapatites and titanium," Ceram. Int., vol. 35, no. 7, pp. 2965-2971, 2009.

[30] J. Nie, J. Zhou, X. Huang, L. Wang, G. Liu, and J. Cheng, "Effect of TiO 2 doping on densification and mechanical properties of hydroxyapatite by microwave sintering," Ceram. Int., vol. 45, no. 11 pp. 13647-13655, 2019.

[31] M. F. Vassal, J. Nunes-Pereira, S. P. Miguel, I. J. Correia, and A. P. Silva, "Microstructural, mechanical and biological properties of hydroxyapatite - CaZrO 3 biocomposites," Ceram. Int., vol. 45, no. 7, pp. 8195-8203, 2019.

[32] J. Song, Y. Liu, Y. Zhang, and L. Jiao, "Mechanical properties of hydroxyapatite ceramics sintered from powders with different morphologies," Mater. Sci. Eng. A, vol. 528, no. 16-17, pp. 54215427, 2011.

[33] M. Figueiredo, A. Fernando, G. Martins, J. Freitas, F. Judas, and H. Figueiredo, "Effect of the calcination temperature on the composition and microstructure of hydroxyapatite derived from human and animal bone," Ceram. Int., vol. 36, no. 8, pp. 2383-2393, 2010 .

[34] W. Khoo, F. M. Nor, H. Ardhyananta, and D. Kurniawan, "Preparation of Natural Hydroxyapatite from Bovine Femur Bones Using Calcination at Various Temperatures," Procedia Manuf., vol. 2, no. February, pp. 196-201, 2015.

[35] E. Barua et al., "Effect of thermal treatment on the physico-chemical properties of bioactive hydroxyapatite derived from caprine bone bio-waste," Ceram. Int., vol. 45, no. 17, pp. 23265-23277, 2019.

[36] M. Boutinguiza, J. Pou, R. Comesaña, F. Lusquiños, A. De Carlos, and B. León, "Biological hydroxyapatite obtained from fish bones," Mater. Sci. Eng. C, vol. 32, no. 3, pp. 478-486, 2012.

[37] T. Goto and K. Sasaki, "Effects of trace elements in fish bones on crystal characteristics of hydroxyapatite obtained by calcination," Ceram. Int., vol. 40, no. 7 PART B, pp. 10777-10785, 2014.

[38] Q. Zhu et al., "The preparation and characterization of HA/ $\beta$-TCP biphasic ceramics from fish bones," Ceram. Int., vol. 43, no. 15, pp. 12213-12220, 2017.

[39] G. Vidhya, G. Suresh Kumar, V. S. Kattimani, and E. K. Girija,
"Comparative study of hydroxyapatite prepared from eggshells and synthetic precursors by microwave irradiation method for medical applications," Mater. Today Proc., vol. 15, pp. 344-352, 2019.

[40] S. Ramesh et al., "Characterization of biogenic hydroxyapatite derived from animal bones for biomedical applications," Ceram. Int., vol. 44, no. 9, pp. 10525-10530, 2018.

[41] C. Piccirillo, R. C. Pullar, D. M. Tobaldi, P. M. L. Castro, and M. M. E. Pintado, "Hydroxyapatite and chloroapatite derived from sardine by-products," Ceram. Int., vol. 40, no. 8 PART B, pp. 13231-13240, 2014.

[42] A. Sobczak-Kupiec and Z. Wzorek, "The influence of calcination parameters on free calcium oxide content in natural hydroxyapatite," Ceram. Int., vol. 38, no. 1, pp. 641-647, 2012.

[43] E. Barua, A. B. Deoghare, P. Deb, S. Das Lala, and S. Chatterjee, "Effect of pre-treatment and calcination process on micro-structural and physico-chemical properties of hydroxyapatite derived from chicken bone bio-waste," Mater. Today Proc., vol. 15, pp. 188-198, 2019.

[44] A. Pal, S. Paul, A. R. Choudhury, V. K. Balla, M. Das, and A. Sinha, "Synthesis of hydroxyapatite from Lates calcarifer fish bone for biomedical applications," Mater. Lett., vol. 203, pp. 89-92, 2017.

[45] G. Muralithran and S. Ramesh, "The effects of sintering temperature on the properties of hydroxyapatite," Ceram. Int., vol. 26, pp. 221230, 2000

[46] M. Safarzadeh, C. F. Chee, S. Ramesh, and M. N. A. Fauzi, "Effect of sintering temperature on the morphology, crystallinity and mechanical properties of carbonated hydroxyapatite (CHA)," Ceram. Int., vol. 46, no. 17, pp. 26784-26789, 2020.

[47] S. Ramesh et al., "Sintering properties of hydroxyapatite powders prepared using different methods," Ceram. Int., vol. 39, no. 1, pp. 111-119, 2013.

[48] A. Karimzadeh, M. R. Ayatollahi, A. R. Bushroa, and M. K. Herliansyah, "Effect of sintering temperature on mechanical and tribological properties of hydroxyapatite measured by nanoindentation and nanoscratch experiments," Ceram. Int., vol. 40, no. 7 PART A, pp. 9159-9164, 2014.

[49] M. Z. A. Khiri et al., "Crystallization behavior of low-cost biphasic hydroxyapatite/ $\beta$-tricalcium phosphate ceramic at high sintering temperatures derived from high potential calcium waste sources," Results Phys., vol. 12, no. December 2018, pp. 638-644, 2019.

[50] M. S. Islam and M. Todo, "Effects of sintering temperature on the compressive mechanical properties of collagen/hydroxyapatite composite scaffolds for bone tissue engineering," Mater. Lett., vol. 173, pp. 231-234, 2016

[51] M. J. Mirzaali et al., "Mechanical properties of cortical bone and their relationships with age, gender, composition and microindentation properties in the elderly," Bone, vol. 93, pp. 196$211,2016$. 